

\title{
A Literature Review: Determinants for Family Takaful Demand in Malaysia - Breaking Out of the Shadow of Conventional Insurance
}

Sofea Arisya Muhammad Shaifuddin

To Link this Article: http://dx.doi.org/10.6007/IJARBSS/v10-i2/6995

DOI:10.6007/IJARBSS/v10-i2/6995

Received: 19 January 2020, Revised: 04 February 2020, Accepted: 12 February 2020

Published Online: 27 February 2020

In-Text Citation: (Shaifuddin, 2020)

To Cite this Article: Shaifuddin, S. A. M. (2020). A Literature Review: Determinants for Family Takaful Demand in Malaysia - Breaking Out of the Shadow of Conventional Insurance. International Journal of Academic Research in Business and Social Sciences, 10(2), 748-757.

\section{Copyright: (C) 2020 The Author(s)}

Published by Human Resource Management Academic Research Society (www.hrmars.com)

This article is published under the Creative Commons Attribution (CC BY 4.0) license. Anyone may reproduce, distribute, translate and create derivative works of this article (for both commercial and non-commercial purposes), subject to full attribution to the original publication and authors. The full terms of this license may be seen at: http://creativecommons.org/licences/by/4.0/legalcode

Vol. 10, No. 2, 2020, Pg. 748 - 757

Full Terms \& Conditions of access and use can be found at http://hrmars.com/index.php/pages/detail/publication-ethics 


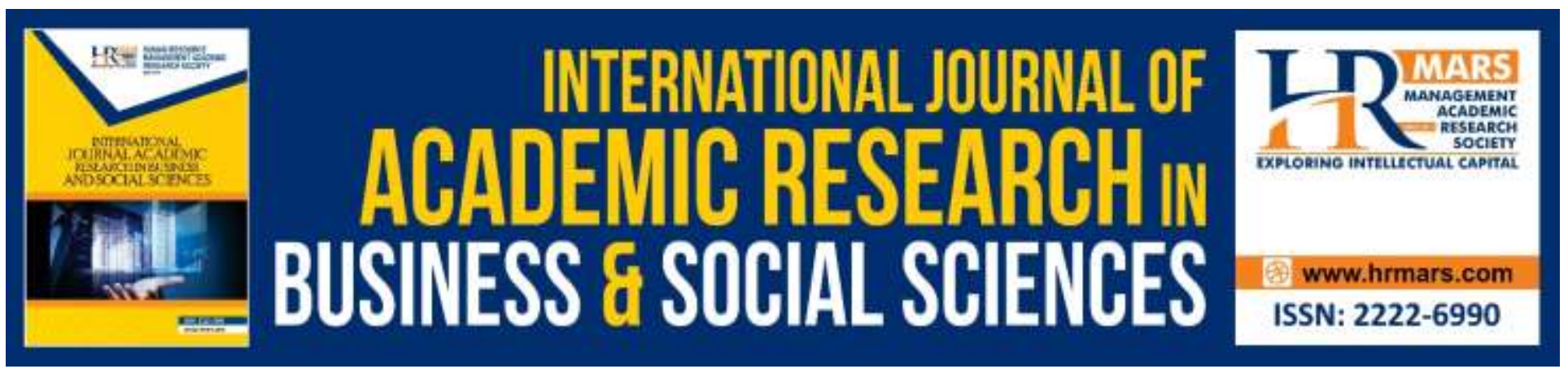

\title{
A Literature Review: Determinants for Family Takaful Demand in Malaysia - Breaking Out of the Shadow of Conventional Insurance
}

\author{
Sofea Arisya Muhammad Shaifuddin \\ Kolej Yayasan UEM, Malaysia \\ Email: sofearisyaa@gmail.com \\ Suhaily Hasnan \\ Universiti Teknologi MARA, Malaysia \\ Email: suhaily77@gmail.com
}

\begin{abstract}
Malaysia is currently regarded as a leading contributor to the Islamic finance industry. Over the last decade, this industry has witnessed tremendous growth across the country. One of the four main markets of the Islamic finance industry is the Takaful industry. This industry is expected to sustain its growth momentum as we move into the $21^{\text {st }}$ century world of technology and innovation. However, Takaful penetration among Malaysians today is still relatively low and stands at only $15.2 \%$ compared to the $61.3 \%$ Muslim population in the country. While the Takaful industry still has a long way to go to be on par with conventional insurance, it has nevertheless laid the foundations necessary to bridge the gap. Several studies have been done to identify the challenges and future prospects of the Takaful industry. This paper aims to discuss the plausible determinants of family Takaful demand in Malaysia as found via a literature review. This study is useful as a guide for stakeholders in the industry to revisit their strategies to gain sufficient momentum, so as to provide a significant challenge to the conventional insurance industry.
\end{abstract}

\section{Introduction}

People cannot escape from the reality of having to sleep-walk into a catastrophe. Undeniably, life is inherently risky. Some risks can be foreseen while some are unexpected, and these risks may affect one's physical health, financial wealth or even business ventures badly. This has made insurance a necessity, instead of a luxury, for all. While many may assume a Muslim-majority country, like Malaysia, has Takaful dominating the insurance market, this is not, and surprisingly, has never been, the case. 
INTERNATIONAL JOURNAL OF ACADEMIC RESEARCH IN BUSINESS AND SOCIAL SCIENCES Vol. 10, No. 2, Feb, 2020, E-ISSN: 2222-6990 @ 2020 HRMARS

Islamic insurance or Takaful is an insurance product which is purely based on Shari'ah compliance. As defined by Bank Negara Malaysia, 'Takaful' is a concept whereby a group of participants mutually guarantee each other against loss or damage. Each participant fulfils his/her obligation by contributing a certain amount of donation (tabarru') to a pool of funds, which is managed by a third party - the Takaful operator. A few elements make Takaful different from its counterpart product, i.e., the conventional insurance product, such as contracts, rights and obligations of the parties, risk ownership, operations and the nominee status (Sherif \& Shairi, 2013). Contrary to the core of conventional insurance, whereby it is a sale and purchase contract, of which the insured buys the promise or undertaking by the insurer of compensation in the event of misfortune, a Takaful contract is based on tabarru' (donation) and ta'awun (mutual cooperation) contracts (Fauzi \& Rashid, 2016). Risks constitute the basis of conventional insurance; however, Takaful differs from conventional insurance, as risks are strictly forbidden under Sha'riah, due to the elements of uncertainty (gharar), interest (riba) and gambling (maysir) (Sharifuddin, Kasmoen, Mat Taha, Mir Ahmad Talaat, \& Mir Ahmad Taalat, 2016). The first element of conventional insurance that is prohibited in Islam is uncertainty (gharar), in which the insured person enters into a bilateral contract with the insurer and pays a monthly premium; the benefit that he will receive is contingent on a loss that may or may not occur in the future. The second element is gambling (maysir), and the third element is riba, where the insurance premiums paid are invested in interest bearing accounts or securities. Consequently, Takaful is considered as the best alternative to conventional insurance, which presents itself as a form of mutual help (taawun), by furthering good values to help others who are in need or in hardship.

According to the World Takaful Report 2016 by Middle East Global Advisors (2016), there are 308 Takaful companies worldwide. The Takaful assets were estimated to be around USD 33 billion around year-end 2014. Muslims account for $61.3 \%$ of the total population of Malaysia, but the adoption of Takaful is still relatively low. The Takaful industry in Malaysia can be considered as still being in the developmental stage or nascent stage (Hassan, Jusoh, \& Hamid, 2014). It is intriguing that in a progressive Muslim majority country, such as Malaysia, Takaful is secondary to its conventional counterpart. Equally surprising is that the penetration of the family Takaful market remains low and lagging behind, with only $14.5 \%$, compared to conventional life insurance, which stood at $41.2 \%$ for the year 2014 (Ernst \& Young \& Malaysian Takaful Association, 2015). Furthermore, Bank Negara Malaysia stated that the net income contribution of Malaysia's Takaful industry stood at RM 9.56 billion and the total assets of Takaful funds was RM 31.37 billion for the year 2018. It can be acknowledged that this amount is small and insignificant compared to the total population of Muslims in Islamic countries, including Malaysia.

The Takaful industry in Malaysia has gone through several changes which has placed the industry as the second largest Takaful market after the Arab region. However, at the rate that this industry is progressing, it is still way below its full potential. There is indeed very strong support from the government, in general, and Bank Negara Malaysia, in particular, but the Takaful industry seems to not be able to shed its image as yet of being an impersonator of its conventional counterpart. The Takaful industry has only succeeded in conquering 13\% of Malaysia's insurance market, compared to conventional insurance at 87\% (Hassan et al., 2014). Between 2014 and 2017, life insurance and family Takaful penetration increased by only $1.1 \%$ a year, resulting in an urgent call out for the industry to step up efforts to enhance its products and business model. Indeed, the effort to enhance 
the Takaful industry's standing vis-à-vis conventional insurance should not just stop here as there are endless possibilities for this industry.

The above scenario has triggered the initiative to further investigate the determinants of family Takaful demand in Malaysia. The low penetration rate of family Takaful market is a wake-up call, to find the determinants of the demand for family Takaful products in Malaysia. Hence, this paper proposes a conceptual framework for the plausible relationships between income, performance of Takaful operators, awareness and knowledge on Takaful and word-of-mouth and the demand for family Takaful in Malaysia.

\section{Literature Review}

Takaful is an important sector in the Islamic finance industry and is showing a positive growth momentum in key markets, such as the in Gulf Cooperation Council (GCC) and The Association of Southeast Asian Nations (ASEAN). In the ASEAN region, Malaysia is one of the two main players, besides Indonesia, contributing almost two-thirds of the Takaful market share (71\%) (Ernst \& Young, 2014). Nevertheless, the size of the Takaful industry is still small compared to other Islamic finance sectors, indicating that the Takaful market still has room for growth, especially in Muslim-majority dominated countries, like Malaysia.

According to Ernst \& Young's World Takaful Report (2010), Malaysia remains the largest Takaful market in Southeast Asia, but there still exists a large untapped market, with only 54\% to 56\% of the population having life insurance or family Takaful policies (Bank Negara Malaysia, 2016). As the Malaysian society prepares for a greater ageing population, efforts must be made to harness the appeal of family Takaful as a tool for long-term savings and investment, whilst protecting against financial vulnerabilities arising from critical illness, death, disability or unemployment, or for providing for children's education (Yazid, Arifin, Hussin, \& Wan Daud, 2012). Many previous studies have investigated the factors that influence the demand for conventional insurance as well as Takaful. With reference to those studies, the remainder of the paper focuses on the propositions on the demand for family Takaful products in Malaysia.

\section{Income}

The income variable has been identified as significantly affecting life insurance/family Takaful demand (Li, Moshirian, Nguyen, \& Wee, 2007; Liebenberg, Carson, \& Hoyt, 2010; Redzuan, Rahman, Sakinah, \& Aidid, 2009). When income increases, insurance becomes more affordable and the demand for family Takaful and life insurance increases as well (Redzuan et al., 2009). Lo, Cheung \& Law (2011) suggested that a person with higher income has a higher tendency to adopt risk reduction strategies, such as by purchasing an insurance policy. This has been proven through the 2004 Current Population Survey (CPS), where $12 \%$ of individuals in families with annual income in the range of USD50,000 to USD74,999 were uninsured, while only $7 \%$ of individuals in families with annual income of USD75,000 and above were uninsured (Fronstin, 2005). In addition to this, the empirical evidence from Cyprus manifests that there would be a C£10 million increase in life insurance premiums for every C $f 100$ million increase in Gross Domestic Product (GDP) (Savvides, 2006).

In the case of Malaysia, there are three different income groups: Top 20\% (T20), Middle 40\% (M40) and Bottom 40\% (B40). The Department of Statistics Malaysia (DoSM), through its Report of Household Income and Basic Amenities Survey 2016, reported that the median and mean household 
INTERNATIONAL JOURNAL OF ACADEMIC RESEARCH IN BUSINESS AND SOCIAL SCIENCES Vol. 10, No. 2, Feb, 2020, E-ISSN: 2222-6990 @ 2020 HRMARS

income for T20 is RM13,148 and RM16,088, respectively. The M40 median and mean household income is recorded at RM6,275 and RM6,502, respectively, while the B40 median and mean household income is registered at RM3,000 and RM2,848, respectively. According to Bank Negara Malaysia (2018), out of the working population (20-59 years old), the B40 life insurance and family Takaful penetration rate is at $30.3 \%$ compared to the national working population penetration rate of $50.4 \%$, as of 2017.

In countries with higher levels of income per capita, the insurance consumption is less elastic to income growth (Hussels, Ward, \& Zurbruegg, 2005). This is consistent with the S-curve hypothesis of Enz (2000), which states that at higher levels of income per capita, insurance consumption becomes less sensitive to income growth as insurance product saturation is reached. The major factor for the occurrence of this situation is that at high-income levels, consumers become so wealthy that they can afford to retain risks within their current financial portfolios (Yazid et al., 2012). Thus, from the previous literature, income could be a plausible determinant of family Takaful demand among Malaysians.

$\mathrm{H} 1$ : There is a positive relationship between income and the demand for family Takaful in Malaysia.

\section{Performance of Takaful Operators}

According to a study conducted by Razak, Idris, Yusof \& Jaapar (2013), service quality is the most significant factor as to why Malaysians choose Takaful products. The results indicate that excellent performance and overall service of Takaful operators has led to a growing demand for family Takaful plans. Besides regulations and financial performance, the main concerns of insurance companies are superior customer experience, efficiency and effective distribution management (Pauli, 2009). The then Governor of Bank Negara Malaysia remarked that that over 50\% of insurance and Takaful complaints that Bank Negara Malaysia received in 2017 were on mis-selling or misrepresentation (Ibrahim, 2018). Thus, this suggests that Takaful operators must shape up and innovate products that are easy to understand and live up to public expectations of fair treatment, as well as transparent and efficient services. This is supported by the study of Bashir \& Mail (2011), which indicates that products which are easily understood is one of the critical reasons for choosing Takaful operators.

To add up to this, Takaful operators have to learn how to migrate to e-payments, as customers favour the online medium these days. Ibrahim (2018) suggested that the industry invests in new technological solutions on its own, or it can partner with others. Hence, insurance players should engage with and promote the online based services for sales, claims and services, to fulfil customers' demands (Pauli, 2009). Furthermore, fair and fast action in processing the claims and willingness to provide consultation when needed, are two of the contributing factors to positive public perception towards Takaful operators (Dorfman \& Cather, 2012). Taking these into consideration, it is proposed that:

$\mathrm{H}$ 2: There is a positive relationship between performance of Takaful operators and the demand for family Takaful in Malaysia.

\section{Awareness and Knowledge on Takaful}

In general, the decision to purchase life insurance/family Takaful product is dependent on the customers' current knowledge and understanding of how insurance or any other financial service or product can benefit or fulfill certain needs (Manab, Rashid, \& Ibrahim, 2004). Customers' awareness 
INTERNATIONAL JOURNAL OF ACADEMIC RESEARCH IN BUSINESS AND SOCIAL SCIENCES Vol. 10, No. 2, Feb, 2020, E-ISSN: 2222-6990 @ 2020 HRMARS

on the existence of a new product in the market is considered as the fundamental stage in the decision-making process (Schiffman \& Kanuk, 1994). Therefore, there is a crucial need for Takaful operators to tackle the issue of low awareness on Takaful products by building trust and confidence among potential customers in choosing their products over conventional insurance. According to the Malaysian Takaful Association (MTA), the local family Takaful industry in Malaysia expanded at a faster pace in 2018 as citizens became more familiar with the Takaful concept (Lim, 2019).

Lack of awareness about insurance and close relatives and friends not making suggestions on the purchase of insurance products, are being viewed as two of the most important barriers to the purchase of health and life insurance (Sarwar \& Qureshi, 2013). The higher the awareness of the public, the higher the probability of them buying health insurance (Bhat $\&$ Jain, 2006). This might be the case for Takaful as well, whereby lack of awareness and knowledge on Takaful products among potential customers, has led to the low demand for family Takaful plans. Hamid \& Othman (2009), conducted a study on the level of knowledge and awareness among Malaysian Muslims towards Takaful insurance and their familiarity with its Shariah terms and concepts. Out of 500 questionnaires distributed, 232 were returned and the results indicate a lack of awareness among Muslims about the core differences between Takaful and conventional insurance. Based on the above discussions, it is proposed that awareness and knowledge on Takaful is a plausible determinant that may influence the demand for family Takaful.

H3: There is a positive relationship between awareness and knowledge on Takaful and the demand for family Takaful in Malaysia.

\section{Promotion by Word-of-Mouth}

The earliest definition of promotion by word-of-mouth (WOM) was put forward by Katz, Lazarsfeld, \& Roper (2017), who described it as the exchanging of marketing information between consumers in such a way that it plays a fundamental role in shaping their behaviour and in changing attitudes towards products and services. WOM provides critical information of a company to customers, which often aids customers to decide their purchase, and in turn, helps the company to attain new customers (Parsa \& Sadeghi, 2015). In the context of insurance purchase, employers as well as insurance agents are extremely relevant in affecting a person's belief to buying insurance plans (Hastings \& Fletcher, 1983).

Studies conducted by Brown \& Reingen (1987) have shown that there are two types of WOM references, namely personal sources, which refer to friends, family and colleagues; and impersonal sources, which comprise comments and writings of journalists, columnists and publications of experts. According to Aziz, Husin \& Hussin (2017), Takaful agents and employers play an important role in delivering WOM to potential customers. In accordance with respective employment policies, employers have high tendency to arrange for family Takaful coverage for their employees and the latter are also encouraged to adopt insurance coverage to their personal liking at their own expense. E-WOM refers to any positive or negative testimonials and comments made by customers about products, services or organisations, discussed openly via online media (Hsieh, Hsieh \& Tang, 2012). It has been suggested that E-WOM among customers is significant as it provides more exposure about the Takaful industry and creates better understanding among consumers on the plans offered (Suki \& Suki, 2019). Therefore, it is obvious that WOM has an impact on the family Takaful demand in Malaysia. 
INTERNATIONAL JOURNAL OF ACADEMIC RESEARCH IN BUSINESS AND SOCIAL SCIENCES

Vol. 10, No. 2, Feb, 2020, E-ISSN: 2222-6990 ¿ 2020 HRMARS

H4: There is a positive relationship between promotion by word-of-mouth and the demand for family Takaful in Malaysia.

\section{Conclusion}

Malaysia has witnessed a robust growth of its Takaful industry over the past 34 years, since its inception in 1985. However, it is important to note that despite the significant growth of the industry, the growth is still lagging. Undeniably, the penetration rate of family Takaful market has shown improvement, when the rate increased slightly to $15.2 \%$ in 2018 from $14.8 \%$ in 2017 , as reported by the MTA. Although the majority of the population in the market is Muslim, the Takaful penetration rate is much lower than the conventional insurance penetration rate, as current market penetration is primarily focused on the more affluent sections of the society.

Previous studies have shown that many reasons have contributed to the demand for family Takaful products among Malaysians, which include the level of public awareness on the concept of Takaful and people's income. These factors that have contributed to the low tendency of Malaysians to subscribe to family Takaful products should be addressed by Takaful operators comprehensively, to elevate the industry to greater heights. Thus, this paper proposes a conceptual framework, which comprises four plausible determinants of family Takaful demand in Malaysia. The determinants reviewed from past literature, include income, performance of Takaful operators, awareness and knowledge on Takaful and word-of-mouth. With the completion of this literature review, it is hoped that this article would assist stakeholders in the Takaful industry to break new grounds to increase the demand for family Takaful products, and simultaneously, clear doubts in the minds of people that Takaful is a mere shadow of conventional insurance.

\section{Acknowledgement}

The authors would like to express their gratitude to Yayasan Khazanah for funding this research project.

\section{Corresponding Author}

Assoc. Prof. Dr. Suhaily Hasnan, Universiti Teknologi MARA, Shah Alam, Selangor, Malaysia

Email: suhaily77@gmail.com

\section{References}

Alzgool, M. (2019). Nexus between green HRM and green management towards fostering green values. Management Science Letters, 9(12), 2073-2082.

Aziz, S., Husin, M., \& Hussin, N. (2017). Conceptual Framework of Factors Determining Intentions towards the Adoption of Family Takaful-An Extension of Decomposed Theory of Planned Behaviour. International Journal of Organizational Leadership, 6, 385-399.

Bank Negara Malaysia. (2016). Financial Stability and Payment Systems Report 2016. Insurance and Takaful Sector, 69-83.

Bank Negara Malaysia. (2018). Expanding Insurance and Takaful Solutions for the Underserved Segment. 1-6. Retrieved from

Bashir, M. S., \& Mail, N. H. H. (2011). Consumer Perceptions of Islamic Insurance Companies in Brunei Darussalam. International Journal of Emerging Science. 
INTERNATIONAL JOURNAL OF ACADEMIC RESEARCH IN BUSINESS AND SOCIAL SCIENCES

Vol. 10, No. 2, Feb, 2020, E-ISSN: 2222-6990 ¿ 2020 HRMARS

Bhat, R., \& Jain, N. (2006). Factoring Affecting the Demand for Health Insurance in a Micro Insurance Scheme. Indian Institute of Management.

Brown, J. J., \& Reingen, P. H. (1987). Social Ties and Word-Of-Mouth Referral Behavior. Journal of Consumer Research, 14(3), 350-362.

Department of Statistics Malaysia. (2017). Report of Household Income and Basic Amenities Survey 2016. Retrieved from

Dorfman, M. S., \& Cather, D. A. (2012). Introduction to Risk Management and Insurance (10th Edition). Pearson.

Enz, R. (2000). The S-Curve Relation between Per-Capita Income and Insurance Penetration. Geneva Papers on Risk and Insurance: Issues and Practice, 25(3), 396-406. https://doi.org/10.1111/1468-0440.00072

Ernst \& Young, \& Malaysian Takaful Association. (2015). Malaysian Takaful Dynamics: Central Compendium 2015, (November), 1-92.

Ernst \& Young. (2010). The World Takaful Report 2010. Managing Performance in a Recovery. April 2010.

Ernst \& Young. (2014). Global Takaful Insights 2014: Markets Updates, 1-16.

Fauzi, P. N. F. M., \& Rashid, K. A. R. (2016). Takaful : A Review on Performance, Issues and Challenges in Malaysia. Journal of Scientific Research and Development.

Fronstin, P. (2005). The Relationship between Income and Health Insurance: Rethinking the Use of Family Income in the Current Population Survey. EBRI Notes, 6(2), 2-6.

Hamid, M. A., \& Othman, M. S. (2009). A Study on the Level of Knowledge and Understanding among Muslims towards the Concepts, Arabic and Shariah Terms in Islamic Insurance (Takaful). European Journal of Social Sciences, 10(3), 468-478.

Hassan, L. F. A., Jusoh, W. J. W., \& Hamid, Z. (2014). Determinant of Customer Loyalty in Malaysian Takaful Industry. Procedia - Social and Behavioral Sciences. https://doi.org/10.1016/j.sbspro.2014.04.043

Hastings, W. J., \& Fletcher, K. P. (1983). The Relevance of the Fishbein Model to Insurance Buying. The Service Industries Journal, 3(3), 296-307.

Hsieh, J. K., Hsieh, Y. C., \& Tang, Y. C. (2012). Exploring the Disseminating Behaviors of eWOM Marketing: Persuasion In Online Video. Electronic Commerce Research, 12(2), 201-224. https://www.bnm.gov.my/index.php?ch=en_publication\&pg=en_work_papers\&ac=66\&bb=f ile

https://www.dosm.gov.my/v1/index.php?r=column/pdfPrev\&id=RUZ5REwveU1ra1hGL21J WVIPRm U2Zz09

Hussels, S., Ward, D., \& Zurbruegg, R. (2005). Stimulating the Demand for Insurance. Risk Management Insurance Review, 8(2), 257-278. https://doi.org/10.1111/j.15406296.2005.00059.x

Ibrahim, M., (2018). Governor's remarks at the Takaful Annual Dinner and Awards 2018: Takaful industry at crossroads: A critical examination. Retrieved from https://www.bnm.gov.my/index.php?ch=en_speech\&pg=en_speech \&ac=793\&lang=bm

Katz, E., Lazarsfeld, P. F., \& Roper, E. (2017). Personal influence: The part played by people in the flow of mass communications. Routledge. 
INTERNATIONAL JOURNAL OF ACADEMIC RESEARCH IN BUSINESS AND SOCIAL SCIENCES

Vol. 10, No. 2, Feb, 2020, E-ISSN: 2222-6990 @ 2020 HRMARS

Khalid, N., Islam, D. M. Z., \& Ahmed, M. R. M. (2019). SENTREPRENEURIAL TRAINING AND ORGANIZATIONAL PERFORMANCE: IMPLICATIONS FOR FUTURE. Humanities \& Social Sciences Reviews, 7(2), 590-593.

Li, D., Moshirian, F., Nguyen, P., \& Wee, T. (2007). The Demand for Life Insurance in OECD Countries. Journal of Risk and Insurance, 74(3), 637- 652. https://doi.org/10.1111/j.15396975.2007.00228.x

Liebenberg, A. P., Carson, J. M., \& Hoyt, R. E. (2010). The Demand for Life Insurance Policy Loans. Journal of Risk and Insurance, 77(3), 651-666. https://doi.org/10.1111/j.15396975.2010.01359.x

Lim, J. (2019). Malaysia's 2019 Takaful Growth to Stay Moderate. The Edge Market. Retrieved from https://www.theedgemarkets.com/article/malaysias-2019-takaful-growth-stay-moderate

Lo, A. S., Cheung, C., \& Law, R. (2011). Hong Kong Residents' Adoption of Risk Reduction Strategies in Leisure Travel. Journal of Travel and Tourism Marketing, 28, 240-260. https://doi.org/10.1080/10548408.2011.562851

Manab, N. A., Rashid, R. A., \& Ibrahim, Y. (2004). Awareness and ownership of Family Takaful scheme among muslim community in Malaysia. Journal of Muamalat and Islamic Finance Research, 1(1), 121-136.

Md Razak, M., Idris, R., Md Yusof, M., \& Jaapar, W. E. (2013). Acceptance Determinants towards Takaful Products in Malaysia. International Journal of Humanities and Social Science, 243-252.

Middle East Global Advisors (2016). Finance Forward World Takaful Report 2016. Connecting the Dots, Forging the Future.

Muhammad, K., Saoula, O., Issa, M., \& Ahmed, U. (2019). Contract management and performance characteristics: An empirical and managerial implication for Indonesia. Management Science Letters, 9(8), 1289-1298.

Parsa, S. Y., \& Sadeghi, T. (2015). Effect of Relationship Marketing on Word of Mouth in Life Insurance with the Approach of Trust and Commitment: Case Study of Karafar in Insurance Agents in Mashhad. International Journal of Management, Accounting and Economics, 2(10), 12441260.

Pauli, K. (2009). Optimizing the Value Chain : Collaborative Customer Knowledge in Global Insurance. Redzuan, H., Rahman, Z. A., Sakinah, S., \& Aidid, S. H. (2009). Economic Determinants of Family Takaful Consumption: Evidence from Malaysia. International Review of Business Research Papers, 5(5), 193-211.

Sarwar, A., \& Qureshi, H.A. (2013). Awareness and Willingness to Buy Private Health Insurance and a Look Into its Future Prospects in Pakistan. European Journal of Business and Social Sciences (EJBSS), 2(1), 69-81.

Savvides, S. (2006). Inquiry into the Macroeconomic and Household Motives to Demand Life Insurance: Review and Empirical Evidence from Cyprus. Journal of Business and Society, 19, 37-79.

Schiffman, L. G., \& Kanuk, L. L. (1994). Consumer Behaviour (5th ed.). New Jersey: Prentice Hall

Sharifuddin, S. S., Kasmoen, N. A., Mat Taha, N. H., Mir Ahmad Talaat, N. S., \& Mir Ahmad Taalat, A. Z. (2016). The Concept of Takaful (Islamic Insurance) and Its Functions in the Establishment of 
INTERNATIONAL JOURNAL OF ACADEMIC RESEARCH IN BUSINESS AND SOCIAL SCIENCES

Vol. 10, No. 2, Feb, 2020, E-ISSN: 2222-6990 @ 2020 HRMARS

Syarikat Takaful Malaysia; the First Takaful Operator in Malaysia. International Journal of Humanities and Social Science Invention.

Sherif, M., \& Shaairi, N. A. (2013). Determinants of Demand on Family Takaful in Malaysia. Journal of Islamic Accounting and Business Research, 4(1), 26-50.

Suki, N. M., \& Suki, N. M. (2019). Investigating the Measurement of Consumers' Electronic Word-ofMouth (E-WOM), Intrinsic and Extrinsic Motives, and Satisfaction of Islamic Insurance (Takaful). Jurnal Komunikasi: Malaysian Journal of Communication, 35(2), 431-447.

Umrani, W., Ahmed, U., \& Memon, P. (2015). Examining the absorptive capacity construct: A validation study in the Pakistani banking context. Management Science Letters, 5(12), 10531058.

Yazid, A. S., Arifin, J., Hussin, M. R., \& Wan Daud, W. N. (2012). Determinants of Family Takaful (Islamic Life Insurance) Demand: A Conceptual Framework for a Malaysian Study. International Journal of Business and Management, 7(6), 115-127. https://doi.org/10.5539/ijbm.v7n6p115 